\title{
Security of Tenure, Costly Tenants and Rent Regulation
}

\author{
J. R. Miron \\ [Paper received in final form, January 1989]
}

Summary. Many jurisdictions give residential tenants legislated packages of rights known generically as 'security of tenure', and some protect tenants further by prohibiting unjustified rent increases. The paper considers the effects of security of tenure on a competitive rental housing market. To illustrate the concepts, the paper describes current security of tenure and rent regulation provisions in the province of Ontario, Canada. A model of rational behaviour by landlords is then presented in which landlords choose simultaneously a rent for a standard lease and the quality of tenant to be accepted. Heterogeneity among landlords and tenants and imperfect information are introduced. The effect of security of tenure legislation on this behaviour is assessed. The paper then considers the difficulty of defining an unjustified rent increase when some tenants are more costly to serve than others and when the landlords have imperfect information about prospective tenants.

In recent decades, many jurisdictions in North America and elsewhere have assigned new property rights to residential tenants. Such packages of rights are generically termed 'security of tenure', although the packages have changed over time and differ among jurisdictions. Miron and Cullingworth (1983) describe an example of this (Ontario) and compare it with other jurisdictions.

In part, security of tenure legislation arises from the same concerns that give rise to consumer protection legislation generally. However, security of tenure is arguably more important because of the significance of having a home, and the location of that home, in terms of one's position and esteem within society and the range of public and private services that one finds nearby. Security of tenure provisions include such things as (i) the maintenance responsibilities of the landlord, (ii) the right of tenants to sublet, (iii) conditions for seizure of premises or contents by the landlord, (iv) access to rented premises by landlords, (v) restrictions on damage deposits, key money and other landlord charges, and (vi) protection against unjustified eviction. Proponents argue that security of tenure gives tenants such benefits as a quiet enjoyment of property, a sense of place and belonging 
within a neighbourhood or community, and a self-respect that comes from freedom from the capricious acts of others.

In several of the above jurisdictions, rent regulation has also been introduced partly to protect security of tenure. As used here, rent regulation refers to modern schemes for screening rent increases with a view to preventing those thought to be unjustified, unlike earlier forms of rent control that froze rents or fixed rents absolutely. Rent regulation is arguably also a tool for achieving other social objectives, such as controlling inflation, redistributing income and maintaining the affordability of housing. The province of Ontario, for example, introduced rent regulation in 1975 at a time when the federal government had just introduced wage and price controls and was urging that the provinces co-operate, within their constitutional jurisdiction, by introducing rent controls. Nevertheless, one important benefit of rent regulation has been to ensure that a landlord cannot otherwise evict a tenant simply by proposing an unjustified rent increase-what has been referred to as an economic eviction.

At the same time, rent regulation imposes certain costs on society generally. It is difficult to measure these costs, although two principal categories are well-known. ${ }^{1}$ There are the not insubstantial costs of administering a programme of rent regulation, these costs falling on governments and landlords directly (and tenants indirectly). There is also the welfare loss arising from rents that are, by fiat, set at inefficient levels.

This paper argues that the market for rental housing is complicated by three characteristics that have significance for any discussion of the impacts of security of tenure and rent regulation legislation. First, there is a spectrum of consumers (i.e. prospective tenants) in the market-place, some tenants being seen by landlords as more costly to serve than others. Second, a landlord typically lacks perfect information about the quality of (i.e. cost of serving) any particular prospective tenant.
Third, landlords are heterogeneous in that they may not each incur the same cost in serving a particular tenant.

Because of these market characteristics, rent regulation imposes a third category of cost to society in the sense that landlords find it more difficult to evict a costly (or 'bad') tenant. ${ }^{2}$ A rational, risk-neutral landlord maximises the difference between the rent obtainable from a particular tenant and the cost of serving that tenant. In a jurisdiction without legislated security of tenure, the market determines the conditions of a lease, balancing the interests of landlord and tenant. Security of tenure legislation shifts that balance in favour of tenants. Landlords attempt to minimise the costs of these non-market provisions rationally by reducing the risk that they will be affected by them, i.e. by discriminating against potential tenants that they might likely later want to evict. Presumably, this makes it more difficult for such new and costly tenants to find rental housing. In this sense, legislated security of tenure also imposes costs for some (i.e. prospective tenants perceived to be costly), at the same time as it may benefit others (i.e. sitting tenants).

Using the province of Ontario, Canada, as an example, this paper examines issues raised by the introduction of security of tenure and rent regulation legislation. The paper briefly reviews the origins of the Ontario legislation, and describes its current security of tenure and rent regulation provisions. The paper discusses the economic role of the residential lease in a competitive rental housing market, and then presents a simple model of landlord rent-setting behaviour. The effects of introducing security of tenure legislation are explored using this model, as is the diffculty of defining the concept of economic eviction.

\section{Security of Tenure in Ontario}

Ontario has had residential landlord-tenant legislation only since 1969 (see Table 
1). Prior to that, no distinctions in statute law were drawn among residential, commercial, industrial or other tenancies, and the rights of residential tenants were protected, for the most part, only in so far as these were stipulated in the lease itself. It is surprising that Ontario enacted this legislation when it did. At the time, there was an unprecedented boom in new rental housing construction. The supply of rental units had increased markedly over the 1960 s, increases in rents had been modest, vacancy rates were not particularly low and the market for private rental housing was quite competitive. Gluskin (1976, p. 134) estimates that the 10 largest publiclyowned builders in Canada produced only 7.4 per cent of the new dwellings sold in Canada in 1976. Gluskin also reports (p. 115) that Cadillac-Fairview Corporation, at the time the largest corporate landlord, and focused on the Toronto market, possessed under 6 per cent of Toronto's total stock of rental apartments. These are not conditions (i.e. either supply restrictions or excess demand) that generally give rise to increased market power among landlords. Why then did Ontario enact this legislation in 1969 ?

In part, public attitudes may have changed because of the emergence of the corporate landlord. Prior to the 1960 s, the rental stock consisted primarily of low-rise buildings of six or fewer dwellings; while data are scarce, it is widely thought that the average landlord owned only one or a few buildings. In the 1960 s, the great apartment construction boom created new, large, high-rise buildings, many owned by corporations, syndicates or other partnerships. To the extent that individual tenants saw these corporate landlords as less personal, or easy to deal with, than the small individual landlord, their emergence may have fostered the growth of landlord-tenant legislation. In part, public attitudes may also have changed simply because security of tenure legislation was part of a new interest in consumer protection generally. As in 'truth in advertising' legislation introduced at about the same time, it was argued that consumers had a right to expect specific performance by a vendor. If, for example, a sum was held as a 'security deposit', the consumer should expect to receive the money back (including interest) at the end of the lease if no unreasonable damage had been done: such deposits were not simply a rent premium to be retained by the landlord. Finally, the 1960s also saw the emergence of a new category of renter household. A substantial proportion of the proliferating number of non-traditional households - those headed by non-family individuals or lone-parent families-became renters. Unlike traditional households, who were quick to move to owner-occupancy when their incomes permitted, non-traditional households appear to have seen renting as a longer-term solution, and may have consequently felt it more important to try to improve the lot of renters generally.

However, by the late 1960 s, it was commonly argued that most tenants had little room to bargain. For a discussion of the results of a recent survey of public attitudes towards fairness in residential tenancies, see Knetsch et al. (1984). The landlord was, by the late 1960 s, widely seen to be free to set lease conditions governing termination and eviction, entry onto the rented premises by the landlord and security and damage deposits. While the terms could not be so onerous that there was no willing tenant, it was widely viewed that market power rested with the landlord, and that the tenant had little recourse against onerous lease provisions. The Ontario Law Reform Commission (1968, p. 43) exemplifies this view:

The landlord and tenant relationship is not, if indeed it ever was, one where tenants have a real freedom to contract. Traditional statements which maintain that a tenant need not agree to the leasing covenants but can seek agreement on more suitable terms elsewhere are not borne out by what happens in the 
Table 1. Ontario legislation governing security of tenure and rent regulation, 1969-87

1969 Landlord and Tenant Act (LTA) proclaimed. LTA takes precedence over lease agreement. In residential tenancies, landlord can evict only with court order. Grounds for eviction are restricted. Upon termination, residential tenancies automatically renew on a monthly basis under LTA unless new lease is signed. Tenants can sublet. Landlords may neither seize contents, nor change locks to the premises. In general, landlord cannot enter a tenant's living quarters without permission or advance notice. Landlords must maintain property in good repair. Landlords are limited to a month's rent as a security deposit; and must pay interest on the latter. Where, at end of tenancy, landlord and tenant disagree about the amount of the damage deposit to be retained by landlord, court approval must be obtained.

1975 Residential Premises Rent Review Act (RPRRA) proclaimed. Initially, guideline rate of increase set at 8 per cent annually; later reduced to 6 per cent. Applies only to rental dwellings in existence prior to 1976.

1979 Residential Tenancies Act (RTA) passed. Part continuing Rent Review from RPRRA was proclaimed immediately; part augmenting LTA provisions re residential tenancies was not proclaimed pending judicial review of constitutionality. Eventually, latter part was found to be unconstitutional. LTA continued to apply to residential tenancies. Guideline rate of increase initially set at 6 per cent; later reduced to 4 per cent. RPRRA repealed.

1986 Rental Housing Protection Act (RHPA) proclaimed.

1986 Rent Regulation Act (RRA) passed to replace proclaimed part of RTA.

RTA repealed. Guideline rates of increase set annually by formula related to changes in costs of maintaining rental buildings. Guideline rates apply to maximum rent; actual rent may be lower, although initial maximum rent was existing rent for rental dwellings in use at enactment, or first rent paid since for newer (or other) dwellings. Rent directory introduced. Rent regulation extended to rental dwellings built since 1976 .

1987 LTA extended to cover roomers and boarders.

real world of landlords and tenants. If protection is necessary for tenants and if a balancing of the interests of the landlords and tenants is to be undertaken, then inevitably, some long-standing concepts must suffer.

\section{Current Security of Tenure Provisions}

With the Landlord and Tenant Act of 1969, the responsibilities and rights of landlords and tenants were set out for the first time in a law that took precedence over any residential lease agreement. Since then, Ontario's security of tenure provisions have been extended. There have been amendments to tighten up loopholes, especially with regard to eviction. In 1987, the legislation was extended to cover roomers and boarders for the first time. Also important was the introduction of rent regulation to be discussed below. In 1979 , the provincial government also undertook a major rewriting of security of tenure provision when it moved coverage of residential tenancies from the Landlord and Tenant Act to new legislation, the Residential Tenancies Act of 1979. However, because of concerns about the constitutional authority of the province to enact some provisions, much of the 1979 Act was never proclaimed, and the rest was effectively repealed after an unfavourable court ruling. Finally, we should note the Rental Housing Protection Act, 1986, which regulates demolition, conversion or vacant possession for the purpose of the renovation of rental residential property. 
Such activity now requires the approval of the local municipal council, and that at least one of three criteria are met: that the premises are no longer fit for human habitation, that current tenants will be accommodated in similar units in the same area, or that the proposal will not reduce the supply of affordable rental housing. Under current legislation, a landlord no longer has the right to evict unilaterally. Instead, the landlord must apply to a court for a writ of eviction (Sect. 121). The grounds for eviction are restricted:

-demolition, conversion or major repairs or renovations (Sect. 107); ${ }^{3}$

-non-payment of rent (Sect. 108); or

- undue damage, illegal acts, interference with reasonable enjoyment by landlord or other tenants, infringement upon safety or rights of other tenants, ${ }^{4}$ or contravention of health or safety standards (Sect. 109).

Simple termination of a lease is no longer a sufficient ground. ${ }^{5}$ Also, a judge may refuse to grant a landlord's application for a writ of possession if satisfied that it would be unfair to do so (Sect. 121). ${ }^{6}$

To illustrate the situation, consider a landlord who wants to evict a tenant for non-payment of rent. Under Sect. 108, a landlord can serve a notice of termination of tenancy upon a non-paying tenant, but this notice cannot be effective for at least 20 days. The tenant then has 14 days to avoid termination by paying any rent demanded. There is no penalty or interest charge for such late payments. Further, where a tenant refuses to pay within the 14 days, the landlord must apply for a writ of possession. However, any application is stayed provided that the tenant pays up in full (i.e. rent in arrears plus court application costs) at any time before a decision is issued. Of some relief to landlords is a provision (Sect. 110) that allows a landlord to apply at the end of term to terminate a lease where the tenant has persistently failed to pay rent when due.

Other rights are assigned to tenants as well. Tenants can sublet, subject only to reasonable objections by landlords (Sect. 91): the tenant is also responsible for cleanliness and repair of wilful or negligent damage (Sect. 96). Landlords may not seize premises or contents unilaterally (Sect. 86), nor may they unilaterally change the locking system on doors to the premises. Except in emergencies, the landlord cannot enter a tenant's living quarters without permission or advance notice (Sect. 93). Landlords must maintain property in good state of repair (Sect. 96). Landlords are not allowed damage deposits; they are limited to a month's rent as a security deposit, and must pay interest on the latter (Sect. 84). Where, at the end of a tenancy, landlord and tenant disagree about the amount of the damage deposit to be retained by the landlord, a judge's approval must be obtained (Sect. 84).

Security of tenure can be provided in various forms. The Landlord and Tenant Act of 1969, for example, did not guarantee a tenant permanent occupancy of a housing unit. For instance, suppose the rent were increased beyond the level a tenant thought affordable. Under the 1969 Act, the tenant had little recourse but to move out. This raised the possibility that a landlord could achieve by raising rents that which might not be possible by court order, namely eviction of an undesirable tenant.

\section{Rent Regulation}

Rent regulation was enacted in Ontario in 1975. Although this marked the first specific reference to 'security of tenure' in Ontario legislation, it actually complemented security of tenure provisions in the 1969 Act. Under the 1975 legislation (the Residential Premises Rent Review Act), landlords could increase rents only once a year. The annual percentage increase was limited by a guideline rate of increase (at first 8 per cent, later 6 per cent), with higher percentages allowed based on "cost pass-through" and "landlord hardship" 
provisions. ${ }^{7}$ Rent Review prevented economic eviction by limiting rent increases to a 'fair' level in these specific senses. There were no restrictions on the initial rents charged for new dwellings; in fact, the Act covered only rental dwellings constructed before 1976. In 1979, the 1975 Act was repealed, and Rent Review was reassigned to the Residential Tenancies Act. The guideline rate of increase was first set at 6 per cent and later at 4 per cent, but otherwise the provisions remained broadly similar.

The restrictions on rent increases under the 1975 and 1979 Acts were weak. There were no penalties to landlords for charging rents in excess of what was permitted except repayment of the excess if caught. Further, there were only minimal restrictions on landlords to prevent them from reducing maintenance or otherwise reducing the cost and quality of the housing they supplied. Finally, cost pass-through and hardship provisions enabled landlords to argue the case for special increases because of renovation, refinancing or repair costs that presumably might otherwise have been funded out of past rent revenues. This weakness was augmented by a lack of information that worked against new tenants. The practice of increasing rents surreptitiously when new tenants moved in was probably commonplace. Not knowing when the rent had last been increased, nor even the previous rent charged, the new tenant was generally not in a position to question whether the rent demanded was legal.

In 1986, Rent Review was replaced by the Rent Regulation Act. The new legislation continued the provisions for annual rent increments (Sect. 49) and for an annual guideline rate of increase (Sect. 50). The legislation differed from its predecessor by specifying a 'maximum rent' on which guideline rates of increase could be compounded, and by providing for penalties for illegal rents, a Residential Rental Standard Board to set and monitor minimum maintenance standards, a rent direc- tory to record maximum rents to enable new tenants to find out about maximum rents that had been previously permitted for that dwelling, and notification of tenants of the maximum rent by landlords. Registration of initial rents was as at 1 August 1985, but currently the rent directory is to apply only to dwellings in structures of six units or more. The maximum rent was either the then current rent, or the initial rent for a new housing unit. Thus, it is possible for landlords, for whatever reason, to charge a rent below the permitted maximum rent in a certain situation, and then later to return to the maximum rent without requiring approval. There is evidence of length-oftenure discounts in rental housing-see, for example, Goodman and Kawai (1985). The maximum rent provision allows landlords to give such discounts without fear of undermining their ability to raise rents substantially for new tenants. In contrast, Guasch and Marshall (1987) argue that the discount is not statistically insignificant. To the extent that the market rent falls below the maximum rent, this provision allows landlords in principle the possibility of threatening economic eviction.

In what follows, I shall refer to the 1975 , 1979 and 1986 Acts collectively as 'rent regulation'. It can be argued that rent regulation is bad because it depresses rents and discourages the construction of new rental housing. However, there is little evidence that rent regulation had substantially depressed rents in Ontario, at least up to 1986; see Steele and Miron (1984, pp. 43-46) and Stanbury and Vertinsky (1985, chapter 6). This may well be because the various guideline, cost pass-through and hardship provisions in conjunction with weakness in enforcement may well have enabled landlords to achieve rents not unlike those that would have been experienced in the absence of rent regulation. But this situation may well be about to change. The 1986 Act eliminated weaknesses in rent regulation that helped keep rents at market levels. With the introduction of the 
rent directory, rent regulation after 1986 became more rigid, raising the possibility that the efficiency loss of rent regulation may grow considerably.

The current debate over rent regulation in Ontario largely ignores its role in security of tenure. Too often, rent regulation has been seen simply as holding down rent increases on average. Throughout this discussion is the general notion that rent regulation should be viewed as a tool for achieving security of tenure, i.e. to prevent economic eviction. To further clarify thinking about the ties between security of tenure and rent regulation, we need a simple model that illustrates how the rental market works and the effects of legislated security of tenure.

\section{The Residential Lease in a Competitive Market}

Let us begin by considering the role of the lease in a competitive rental housing market. Assume initially that the market is not governed specifically by landlord-tenant legislation, although there may well be regulatory constraints imposed by common law or statute. On the one hand, the tenant typically lacks information about the behaviour to be expected of the landlord. The tenant may, for example, want 'quiet enjoyment' of the property for a period of time, e.g. unrestricted access by the tenant to the rented premises, adequate maintenance of the property and quick repairs by the landlord, suitable provision of heat, water and other utilities, freedom from undue eviction, protection from neighbouring tenants who become unruly or noisy and control over access to the rented premises by the landlord. However, in an otherwise unregulated market with imperfect information, the tenant may simply not be confident that the landlord will behave appropriately. Even if the tenant has confidence in the current landlord, the dwelling might be sold at some future date to a new landlord who might behave differently.
On the other hand, the landlord usually also does not have perfect information, and must usually announce an asking rent in advance. In renting, there is the risk that the tenant will prove subsequently to be more costly to serve than expected-for example, through waste heat or energy, vandalising or causing extraordinary damage or wear and tear to the property, being tardy in paying rent, being noisy, unsanitary, dangerous, unruly or disruptive, or otherwise being a bad tenant. Of course, the landlord could in principle charge a price (rent) that is sufficiently high to offset expected costs of this type, but there is always the risk of the adverse selection problem, that even a higher rent will prove to be insufficient, and, in the absence of better information about the prospective tenant, that higher rents might repel less costly prospective tenants (Stiglitz and Weiss, 1981).

In practice, landlords and tenants employ a mix of price (i.e. rent) and lease conditions (i.e. non-price tools) to achieve their objectives. In other words, a lease is simply a contract, and in the words of Rosen (1985, p. 1145),

A contract is a voluntary ex-ante agreement that resolves the distribution of uncertainty about the value and utilisation of shared investments between contracting parties.

A lease typically sets out, among other things, the length of the contract and options for renewal, a schedule of rents, performance standards to be met by landlord or tenant, penalties for failure to perform and conditions for termination. In an otherwise unregulated market, the landlord and tenant are free to draft the terms comprising the lease. In a competitive market, one can imagine that there exists a 'standard lease' and associated rent, that for either party is the best alternative, or opportunity cost. To the extent that a negotiated lease differs from this standard lease, it offsets a more favourable condi- 
tion for the tenant by a lease provision (e.g. a higher rent) valuable to the landlord.

Up to this point, we have painted a simple picture of the process by which leases are negotiated. The analysis becomes more complex if it is recognised that any contract is incomplete in the sense that there are future contingencies that cannot be fully anticipated. The lease can be viewed as a contract wherein uncertainty is reduced, but not eliminated, and where the two parties agree to mutual restrictions and guarantees designed to ensure the wellbeings of both landlord and tenant. In that case, an additional important complexity is opportunism, which Williamson (1985, p. 47) defines as "self-interest seeking with guile". Thus, for example, ex ante opportunism arises when the landlord or tenant misrepresent themselves to the other in a way that makes it difficult for the other party to correctly assess the risks involved in the lease. Ex post opportunism arises when either party to the contract fails "to behave in a fully responsible way and take appropriate risk-mitigating actions" (Williamson, 1985, p. 47).

\section{Rent in a Simple Model of a Competitive Market}

Consider the following simple model of rational behaviour by the landlord. Suppose the landlord has two choices: the monthly rent to be charged $(r)$ over a specified period of time for a standard lease, and the minimum quality of tenant to be accepted $(q)$. What follows is a very simplified model of landlord behaviour. Notably, it ignores the quality of the dwelling unit and the dynamics of maintenance by which a landlord might seek to match the quality of dwelling to the quality of tenant; Vorst (1987) exemplifies an approach to maintenance that might usefully be combined with the model presented in this paper. Since the model is intended to focus on the heterogeneity of tenants, it deliberately ignores other supply considerations, such as production techno- logy, input prices and substitutability, and financing, that are also important to landlords. Suppose $p$, the proportion of time that the dwelling is rented during the specified period, is negatively related to $r / R$ (where $R$ is some market 'norm rent') and to $q .^{8}$ Suppose further that the landlord's costs are the sum of a fixed monthly cost, $C$, and a variable cost, $c$, that is negatively related to $q .^{9}$ If the landlord maximises expected monthly profits, his decision problem can be characterised as follows:

$$
\underset{q, r}{\operatorname{Maximise}} p[r / R, q][r-c(q)]-C
$$

In other words, the landlord chooses from among several different quality-of-tenant submarkets, and does not always pick the best-quality tenant. Market conditions may make it more profitable for the landlord to serve a costly (i.e. low $q$ ) consumer. In such situations, a higher rent and/or lower likelihood of vacancy combine to overcome the higher cost of serving this kind of tenant. A rational landlord would set a rent taking into account the effect of a higher $r$ on potential gross revenue on the one hand, and on $p$ on the other (see, for example, Steele and Miron, 1984).

\section{Equilibrium with Identical Landlords}

Viewed this way, the rental housing market is a set of submarkets for housing at different levels of $q$. In many cases, accommodation can be moved costlessly by landlords from one $q$-submarket to the next. Suppose that there are enough identical landlords, enough flexibility in the housing stock and enough tenants of each type to assume competitive markets. There therefore exists an equilibrium assignment of housing to quality-of-tenant submarkets that leaves landlords indifferent among alternative assignments, i.e. that all submarkets are equally profitable. In such an equilibrium, the difference in rents between two quality submarkets for two otherwise identical dwellings reflects 
changes in $c[q]$ and $p[r / R, q]$. In other words, market rent, $r$, is a declining function of $q$ in equilibrium, corresponding to what might be called an equiprofit locus (EPL).

To see further implications of this model, it is helpful to think of EPL initially in terms of $[r, c(q)]$. Above, we have already assumed that the landlord is riskneutral in the sense of maximising expected value. What form might EPL take? One possibility is that changes in $r$ will match, dollar for dollar, the change in $c[q]$ : i.e. that more costly tenants will exactly pay their marginal costs vis-âa-vis less costly tenants. This is illustrated by the linear EPL in Figure 1. However, for this to happen, $p[r / R, q]$ must remain constant across all $q$. If, in fact, the price sensitivity of demand varies across quality submarkets in a way that makes $p[r / R, q]$ vary, then EPL will be non-linear. The relationship will also be non-linear if the landlord is not risk-neutral.

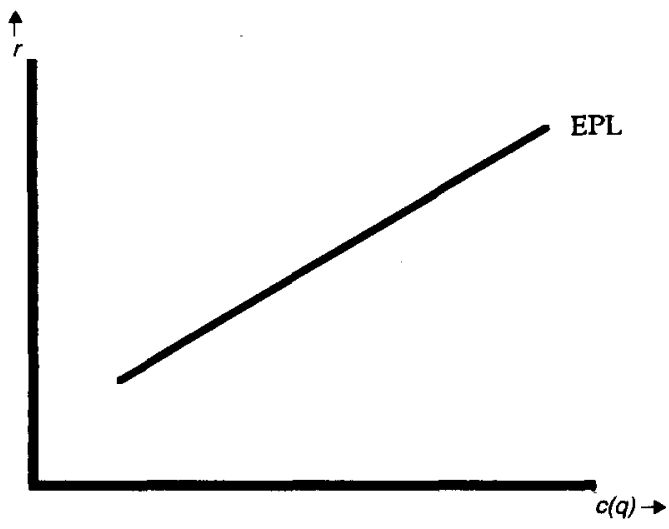

Figure 1.

There are, in fact, a family of EPL curves, each of which defines a unique level of profit (see Figure 2). Lines upward and to the left in Figure 2 (i.e. viewed in terms of $r$ and $c(q)$ correspond to greater profits (or, more generally, landlord utility). Corresponding to this is a family of EPL curves drawn in $(r, q)$ space and illustrated in Figure 3, whose shapes are determined by the factors noted above as well as by the particular form of the function $c(q)$. Without loss of generality, EPL can also be drawn as linear in $(r, q)$, since $q$ can be arbitrarily set as a negatively-sloped linear function of $c(q)$. Of course, one EPL generates zero excess profits (ZEP), and in a competitive equilibrium this is the EPL to which market rents are forced. This is shown as EPL2 in Figure 3. In this case, market rent differentials across $q$-submarkets exactly match differences in $c(q)$.

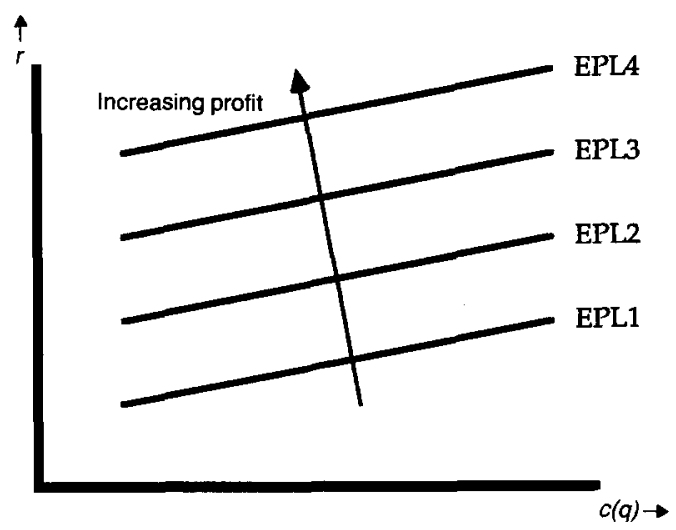

Figure 2.



Figure 3.

\section{Equilibrium with Different Kinds of Landlords}

To the landlord, the costs of handling tenants of different quality are only in part 
monetary. In part, the costs also include the time that the landlord must spend dealing with tenants and the frustration that may arise in such dealings. Let us suppose that landlords come in two kinds: type 1 and type 2. Type 2 landlords experience only modestly greater costs in handling lowquality $v i s-\dot{a}$-vis high-quality tenants. On the other hand, type 1 landlords find it relatively more costly to serve low-quality tenants, and less costly to serve those of high quality. Such a differentiation of landlords might well be expected if landlords differ in their level of risk aversion. Also, given economies of scale in rental building management, it might be argued that large landlords are more likely to be of type 2, and landlords with few properties are more likely to be of type 1 . Suppose that the EPL corresponding to zero excess profits in the two cases are given by ZEP1 and ZEP2 for type 1 and 2 landlords respectively in Figure 4. Given enough landlords of each type, the market rent for each quality submarket is then given by the lower envelope curve to ZEP1 and ZEP2. In Figure 4, all tenants below quality $s$ would be allocated to type 2 landlords: those above $s$ to type 1 landlords.

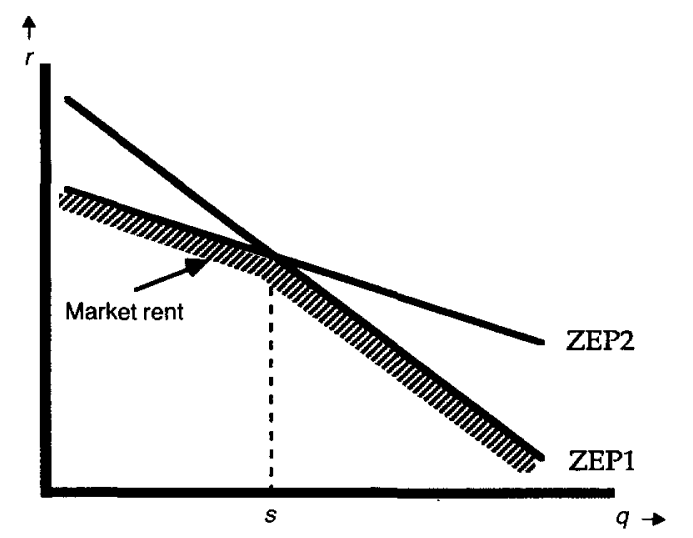

Figure 4.

This argument is easily extended to cover the case of more than two types of landlords. For each type, we can find the ZEP locus. Superimposing all of these

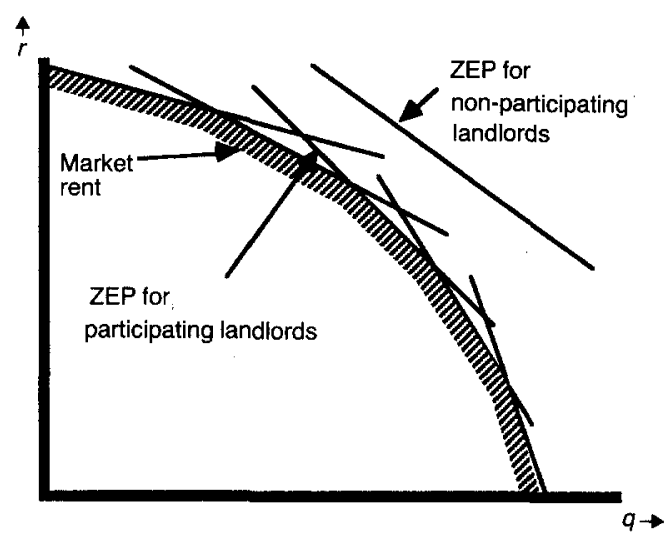

Figure 5.

EPLs on the same diagram as in Figure 5 allows us to find the market rent as the lower envelope curve again. Any landlord whose EPL does not rest on this envelope curve will be driven out of the industry. In general, this differentiation among landlords implies that market rents may change across $q$-submarkets by less than the increase in cost of serving tenants as perceived by any one type of landlord.

\section{Uncertainty}

However, this model is still overly simple in at least one important respect. In practice, the landlord does not know exactly in which quality market he is operating when he accepts a new tenant. In many cases, there is simply an absence of information about the tenant; in other cases, the tenant behaves in an opportunistic fashion. There are means available to the landlord to help predict $q$. For example, the landlord might screen potential tenants using information from other landlords, or from credit agencies. The landlord may also be able to affect $q$ by imposing restrictions on the size, composition or income of the household. Perhaps $q$ can also be partly determined by the rent that is charged, or by the kind of facilities and amenities that are provided with the accommodation. Nonetheless, there is generally some uncertainty about the quality level of a particular new tenant: whether it be from lack of informa- 
tion, or from opportunism on the part of the tenant.

This uncertainty means that, in market equilibrium, there is a probability distribution of rents determined by the level of information available to landlords. It has another important implication for rentsetting by landlords. Suppose that each potential tenant has a given $q$ that is initially unknown to the landlord, but revealed during the tenancy. The landlord can think of the tenant's $q$ as a random variable (with an expected value, $E(q)$ ). The initial optimal rent must take into account the costs of overestimating and underestimating the tenant's $q$. If $q$ is overestimated, the rent will be set too low for what proves to be a costly tenant. If $q$ is underestimated, the rent might be set too high in the sense of having an inefficient probability of vacancy downstream.

Uncertainty about $q$ may help explain the phenomenon of length-of-tenure discounts wherein landlords charge old tenants lower rents than they do new tenants. If the rental market is tight (i.e. low vacancy and high application rates), the cost of underestimating $q$ will be low in that the unit will not stay vacant long if the new tenant subsequently leaves. On the other hand, the cost of overestimating $q$ also depends on how easily or quickly the lease of a costly tenant can subsequently be terminated. If the cost of marginally overestimating is greater than the cost of marginally underestimating $q$, and the density function for $q$ is symmetric about $E(q)$, the landlord will maximise expected profits by setting a rent above the amount corresponding to $E(q)$. Once the tenant's $q$ becomes known to the landlord, the optimal rent would likely become smaller. This would be equivalent to a length-of-tenure discount. Of course, it is also possible that the landlord initially overestimated the tenant's $q$ by enough that it is subsequently necessary to increase the rent still more or seek an eviction. In other words, most old tenants may appear to be receiving lengthof-tenure discounts because their more costly peers have since been evicted or encouraged to leave, and now show up as new tenants living elsewhere. It should be added that this argument is intended to complement, not to discount, other reasons why length of tenure discounts might exist.

\section{Impact of Security of Tenure Legislation}

Suppose we now introduce security of tenure legislation into this model. Suppose further that this legislation is binding on the market in the sense that it results in a new standard lease (hereinafter referred to as an enhanced lease) that has certain conditions more advantageous to the tenant than had previously existed in a standard lease. Finally, suppose initially that this legislation does not provide for rent regulation. The above analysis is then changed in two important respects.

First, the ZEP for any type of landlord in Figure 5 will shift upward. The landlord will seek to offset onerous security of tenure requirements with other, new, more favourable lease conditions, including (but not limited to) a higher rent. Under the enhanced lease, the cost of providing housing to a tenant of a given quality increases in so far as the legislation dictates that every tenant now has to be provided with what to the landlord is a more expensive set of services. In this sense, we can think of the enhanced lease as an old standard lease plus additional offsetting provisions for tenants and landlords. Will society necessarily be worse off, in an efficiency sense, as a result? Given perfect information, society cannot become better off since there is nothing to prevent an unregulated market from moving to an enhanced lease directly if superior. On the other hand, society will not be worse off if landlord and tenant are indifferent between standard and enhanced leases. If the rental market is a small component within a much larger perfectly competitive economy without barriers to entry or exit, the rate of return to being a landlord will settle 
at some 'normal' rate. With the introduction of security of tenure legislation, the rate of return might initially change but landlords would enter or leave the industry until the normal rate of return was reestablished. In this case, the rate of return to landlords would be the same as before, and landlords would be indifferent between the standard and enhanced leases.

However, because of differences among landlords, the impact on rent may not be the same for every tenant, even if the added cost is identical for every $q$. To see this, consider Figure 6, wherein there are two types of landlords. In an unregulated world, they can be characterised by ZEP1 and ZEP2. Suppose that, with the introduction of security of tenure legislation, these two curves shift up to ZEPl' and ZEP2' respectively. Since the market rent is the lower envelope of these curves, it too shifts upward for any given $q$. There is, however, another important change. In the unregulated market, type 1 landlords get all tenants above quality $s$ : lower-quality tenants going to type 2 landlords. With security of tenure legislation, landlords of type 1 take only tenants above $s^{\prime}$. We do not know for sure if $s<s^{\prime}$ as shown. However, we can say that all tenants between $s$ and $s$ in equilibrium will be reassigned to the other type of landlord and may consequently face different rent increments from tenants at other values of $q$.

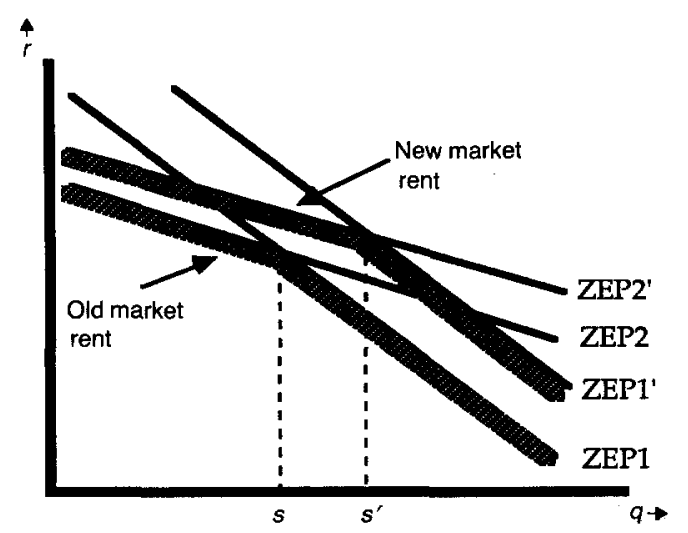

Figure 6.
A second impact of security of tenure legislation arises because of uncertainty in the market and the heterogeneity of landlords. In an unregulated market, landlords can insist on damage deposit, entry and inspection, and eviction provisions in the lease as ways of limiting the risks and costs of having a bad tenant. Security of tenure legislation by restricting some or all of these, reduces the ability of landlords to reduce tenant ex post opportunism, or to cope with tenants who prove to be of an unexpectedly low $q$ : increasing costs to landlords and shifting ZEP upwards.

At the same time, since landlords may well differ in temperament and valuation of time, and since they lack information about a prospective tenant's $q$, the introduction of security of tenure legislation affects individual landlords differently. Other things being equal, landlords with a high value on their time, and those who are easily frustrated or angered by 'uncooperative' tenants, will experience the greatest upward shift in ZEP. In extreme cases, the introduction of security of tenure legislation could cause the ZEP for such landlords to shift upwards by so much that these landlords leave the market, i.e. their ZEP lies entirely above the lower envelope that defines the new market rents. At the least, it means that such landlords will be competitive over a narrower range of $q$ after the introduction of security of tenure legislation.

This is illustrated in Figure 7, where three types of landlords are shown. MR is the market rent curve before security of tenure is introduced; $\mathrm{MR}^{\prime}$ is the market rent curve afterwards. Underlying this, in part, is a shift from ZEP2 to ZEP2' for landlords of type 2 ; in equilibrium, these landlords shift from serving tenants between quality levels $t$ and $s$, to instead serve those from $t^{\prime}$ to $s^{\prime}$. What happens to sitting tenants between $t$ and $t^{\prime}$, or between $s$ and $s^{\prime}$ ? In equilibrium, either they relocate, or the current landlord sells the property to another landlord of the appropriate type. Without such a change, either 




Figure 7.

the tenant would be paying in excess of the market rent for that $q$, or the landlord would have to accept a rent that was below the new ZEP.

\section{Economic Eviction}

In the Ontario scheme, and elsewhere, rent regulation does serve to prevent economic evictions. The Ontario scheme, by allowing guideline rates of increase, cost passthrough and landlord hardship, gives landlords freedom to make modest changes but requires review and approval when large increases in rents are proposed. Under such a scheme of rent regulation, landlords no longer have the right to impose large rent increases, unless these can be specifically related to increasing costs.

However, at the same time, the Ontario legislation does not recognise that some tenants are more costly to serve than others. For the most part, landlords cannot increase rents substantially for tenants who prove to be worse than expected. In a sense, the 1986 Ontario amendments are more flexible. By calculating rent increases on the maximum rent while permitting actual rents to be lower, landlords can potentially increase rents substantially if a tenant proves to be more costly than expected. However, a landlord's room to manoeuvre is limited to the gap between the maximum rent and the rent currently charged. By closing options to landlords, rent regulation serves to increase the costs of having bad tenants and makes landlords more cautious about erring in assessing the quality of prospective tenants. In effect, since the landlord is free to set the rent for a new dwelling with only future increases being regulated, the Ontario system forces landlords to make an initial choice of $q$ submarket and may prevent them from subsequently moving easily between $q$ submarkets where the rent difference is substantial. In other words, in attempting to prevent economic eviction, rent regulation may damage market mechanisms for the efficient handling of heterogeneity among tenants.

Another problem with rent regulation becomes clear when we attempt to become more precise about the meaning of economic eviction and why it exists. Different definitions of economic eviction are possible. Let us consider some possibilities to better understand what was intended in the case of the Ontario legislation.

One possible definition begins from the argument that a sitting tenant should be allowed to remain in a dwelling regardless of whether it is affordable. Of this view are those who say that the rent should be tied to the tenant's income, with rent being reduced if income drops. In this view, anyone forced to move because their income drops is a victim of economic eviction. Does Ontario rent regulation emphasise affordability in this way? In the early years (1975-85), there was no publicly announced formula for the guidelines. If Ontario's guideline rates of increase were set by increases in consumer income, then arguably the Ontario scheme related economic eviction to affordability, at least in general terms. On the other hand, if guidelines were tied to increases in the cost of providing housing services, as they have been in more recent years, then affordability is not central to the design of the scheme.

Others argue that tenants should be able to remain in a dwelling for as long as they can afford a 'fair' rent, albeit with different 
conceptions of what is fair. Some believe that a fair rent reflects the initial cost of producing the dwelling and any normal maintenance and operating costs, i.e. historic costs, and specifically exclude costs that result from a major renovation, or from a sudden shift in demand. They include, as economic evictions, cases where a tenant is forced to move because the dwelling has been substantially remodelled and the rent has risen correspondingly. Again, it is not clear just how this issue is viewed in the Ontario scheme. On the one hand, since units undergoing major renovations are momentarily exempt from rent regulation upon reoccupancy, the associated preceding dislocations are not seen as economic evictions. Even so, the Rental Housing Protection Act has made it more difficult to obtain eviction for this purpose. On the other hand, the Ontario scheme, in providing for guideline rates, cost pass-through and landlord hardship, does not take account of variations among local markets, although provision is made in the 1986 legislation, as yet unproclaimed, for the increase of "chronically depressed rents'. The guideline rate of increase, for example, is the same in the buoyant downtown Toronto market as in an economically depressed rural area. By serving to prevent rent increases that are above guidelines in local markets under strong demand pressure, the Ontario scheme suggests that such demand-pushed rent increases would be economic evictions. On the other hand, if guidelines are set high enough to encompass almost all local market conditions, arguably the Ontario scheme does not consider demandpushed rent increases as economic evictions.

Another possibility is to define an economic eviction as being when a landlord seeks a rent increase that is out of line with rents that a household would face elsewhere in an uncontrolled market for similar accommodation from a similar and equally knowledgeable landlord. In other words, a justified rent is one determined in the market-place. It reflects the quality characteristics of the dwelling, a standard set of lease conditions and the demand for, and supply of, that quality of accommodation. It also recognises that households are not all identical. This is different from the definition in the preceding paragraph. For example, the landlord who renovates a dwelling and then raises the rent does not engage in economic eviction, under the present definition, unless the new rent is excessive relative to what the tenant could expect to pay for other similar dwellings in an uncontrolled market.

However clear the latter definition is in principle, it is difficult to operationalise in practice. In part, this is because it is difficult to know whether the landlord is attempting economic eviction or simply reflecting the cost of serving a particular kind of tenant. As with tenants, most landlords are rational. They know what will happen if they charge a rent in excess of the going market price. Either their dwelling will not rent, or, given imperfect information, they will eventually get a tenant only to have that person move out again shortly and see the dwelling remain vacant for an extended period until another willing tenant comes along. In general, a landlord who wants to remain in the business must trade off the gains from a higher rent against the increased likelihood of a vacancy..$^{10}$ Maybe the landlord can exploit the tenant's imperfect knowledge of the rental market to obtain an unfair rent. Or perhaps a landlord might exploit the moving costs facing a current tenant to extract a higher rent than could be obtained from a prospective new tenant. However, such cases aside, it would generally not be rational to charge a rent in excess of the market level. Therefore, why would a landlord knowingly seek a rent that results in economic eviction?

In a rational world, it is difficult to imagine why economic eviction occurs. One possibility is that the tenant lies on a portion of the landlord's ZEP that does not coincide with the market rent curve. In 
Figure 7, a landlord of type 2 (post-security of tenure) would need to charge a tenant of quality $q<t^{\prime}$ or $q>s^{\prime}$ a rent above market to achieve ZEP. Kindly put, the landlord may seek eviction simply because there are more efficient suppliers of rental housing services in that submarket. Another possible reason for economic eviction is that the landlord initially estimated the quality of a tenant wrongly and, in the midst of the tenancy, realises that net profit could be increased by replacing that tenant with another. However, given security of tenure provisions, the tenant might not be sufficiently bad to be evicted. Instead, the landlord might choose to raise the rent substantially, thereby inducing the tenant to leave. This is equivalent to saying that the tenant lies outside the submarket within which the landlord can efficiently compete. However, to argue that this should be prevented is to assert that the market should be prevented from efficiently allocating tenants to landlords.

Why, then, do we regulate rents if it can be argued that it is inefficient? Up to this point, we have assumed that a landlord is always rational, which in turn is to deny one of the basic arguments for having security of tenure legislation. At the outset of this paper, one objective of security of tenure was stated to be promotion of the sense of self-respect that arises from freedom from the capricious acts of others. Capriciousness and rationality are rarely heard in the same sentence. In the real world, irrational behaviour is not unheard of. While competition may eventually drive irrational landlords out of the market-place, it is also true that many tenants may be unnecessarily hounded along the way.

At the same time, this discussion introduces another argument in favour of rent regulation. We have already enumerated some of the costs to the landlord of having a bad tenant. Presumably, these include out-of-pocket costs, and imputed costs such as foregone interest on tardy rent payments, and loss of rental revenue on any resulting dwelling vacancies after the departure of a bad tenant or his neighbours. There are also the imputed costs of the time and effort expended by a landlord handling a bad tenant. The latter poses a problem for those who would abolish rent regulation. How does one know whether or not a stated rent increase correctly reflects costs, when the costs are not entirely measurable? Is it reasonable for a landlord to double the rent, for example, because a bad tenant causes frustration or takes up a lot of time? The problem is that almost any rent increase can be justified if a suitable weight is put on what are largely intangible costs to the landlord. At an extreme, one might argue that there are no economic evictions at all, but merely landlords with high valuations of their time, effort and convenience.

Also, this raises a fundamental issue in security of tenure. Suppose a tenant's only fault is to organise an association to bargain with the landlord. In the landlord's view, such a tenant might cause him considerable frustration and expended time, and hence is costly. To the landlord, a rent increase is rational. However, from society's viewpoint, this would detract from the goals that security of tenure legislation is designed to promote. Given that it is important to protect the rights of tenants, rent increases, or the prospect of a rent increase, might penalise tenant participation.

\section{Conclusions}

Let us now summarise the argument. The quality of tenants does appear to vary; landlords perceive some tenants to be good and others as more costly to serve. An efficient market requires rents differentiated by quality of tenant. Lacking perfect information about the quality of a new tenant, landlords must choose an initial rent and then adjust the rent later on as they gain experience with the tenant. Such adjustments can be either up or down. Length-of-tenure discounts are not uncom- 
mon, however; upward adjustments may also be appropriate, and may not necessarily constitute economic evictions (depending on one's choice of definition). To preserve efficiency, rent regulation has to be flexible enough to permit such adjustments.

There is a roll for legislation such as rent regulation which prevents such economic evictions. Without it, tenants are vulnerable to the caprices of landlords. In effect, rent regulation is intended to prevent a kind of discrimination. One can envisage alternative forms of legislation that serve the same purpose. One alternative is to assume discrimination wherever the rent asked of a departing tenant exceeds that paid by the new tenant. However, rather than being discriminatory, the landlord may simply have initially overestimated the market rent, then reduced the asking price after the unit had been vacant awhile. Also, this alternative would require that the departing tenant knows the rent charged to the new tenant. However, any form of regulation creates costs, even as it provides benefits. Rent regulation is costly, both in terms of direct costs of administration and in terms of compliance and other indirect costs. There is not much point in protecting the rights of tenants if the benefit gained is small. In addition to the well-known costs of administration and the efficiency welfare loss of holding rents below equilibrium levels, the model developed in this paper emphasises the cost to landlords of the increased difficulty of evicting a costly tenant.

\section{Notes}

1. Two studies have attempted to measure the costs of rent regulation. One is Smith and Tomlinson (1981). However, their analysis has several shortcomings, as noted in Miron and Cullingworth (1983, pp. 20-41). The other is the Ontario Ministry of Municipal Affairs and Housing (1982). The latter is a somewhat more careful assessment, but it relies in several places on the analysis of Smith and Tomlinson. In short, there does not appear to be a satisfactory assessment of the overall costs of rent regulation. Such an analysis would be an important part of any informed debate over the future of rent regulation.

2. Steele and Miron (1984), and related ideas in Henderson and Ioannides (1983) and Ricketts (1982).

3. Although the tenant has the right of first refusal to reoccupy a dwelling upon completion of major repairs or renovations. Further protection is afforded tenants by the Rental Housing Protection Act, 1986, as noted above.

4. Makuch and Weinrib (1985) point out that there is no provision in the Act for tenants to seek eviction of their noisy or unruly neighbours.

5. Upon termination, all Ontario residential tenancies are assumed in law to automatically renew on a monthly basis unless a new agreement is reached between landlord and tenant (Sect. 106).

6. Further, the judge is to refuse to issue a writ where (i) a landlord is in breach of responsibilities, (ii) the reason for the application is that the tenant has complained to a government agency of a violation by the landlord, or otherwise attempted to secure or enforce his or her legal rights, or (iii) the reason for the application is the presence of children.

7. Under the 1979 Residential Tenancies Act, these provisions are described in Sect. 125 and Sect. 131.

8. $R$ will vary depending on the quality of the tenant and the level of information in the market about his/her quality.

9. Henderson and Ioannides (1983) argue that the tenant determines the "rate of utilization" of an existing housing unit, e.g. the use of fuel and utilities, and general wear and tear. To the extent that utilisation exceeds the landlord's expectations, the tenant may be seen to be costly by the landlord.

10. Suppose that the probability of renting a dwelling at a monthly rent of $r$, relative to some market norm rent, $R$, is $p[r / R]$. Maximising expected monthly rent, i.e. $r[p(r / R)]$, leads the landlord to set $\mathrm{d} p / \mathrm{d} r=-p / r$.

\section{References}

Gluskrn, I. (1976) Cadillac-Fairview Corporation Limited: a corporate background report. Study No. 3, Royal Commission on Corporate Concentration. 
Goodman, A.C. and KawaI, M. (1985) Lengthof-residence discounts and rental housing demand: theory and evidence, Land Economics, 61, pp. 93-105.

GUASCH, J.L. and MARSHALl, R.C. (1987) A theoretical and empirical analysis of the length of residency discount in the rental housing market, Journal of Urban Economics, 22, pp. 291-311.

Knetsch, J.L., Kahneman, D. and McNeil, P. (1984) Residential tenancies: losses, fairness and regulations. Research Study No. 14, Ontario Commission of Inquiry into Residential Tenancies.

HeNderson, J.V. and IoANNides, Y.M. (1983) A model of housing tenure choice, American Economic Review, 73, pp. 98-113.

MaKUCH, S.M. and WeINRIB, A. (1985) Security of tenure. Research Study No. 11, Ontario Commission of Inquiry into Residential Tenancies.

Miron, J.R. and CullingworTh, J.B. (1983) Rent Control: Impacts on Income Distribution, Affordability, and Security of Tenure. Toronto: Centre for Urban and Community Studies, University of Toronto.

Ontario Law Reform Commission (1968) Interim Report of the Ontario Law Reform Commission on Landlord and Tenant Law Applicable to Residential Tenancies. Toronto: Ontario Department of the Attorney General. OnTARIo Ministry OF MUNICIPAl AfFaIRs AND
HousING (1982) The Impact of Rent Review on Rental Housing in Ontario: a Staff Research Report. Toronto: Ontario Ministry of Municipal Affairs and Housing.

RickeTts, M. (1982) A model of the furnished rented housing market under regulation, Scottish Journal of Political Economy, 29, pp. $1-21$.

ROSEN, S. (1985) Implicit contracts: a survey, Journal of Economic Literature, 23, pp. 1144-1175.

Smith, L.B. and TomLinson, P. (1981) Rent controls in Ontario. Roofs or ceilings?, Journal of the American Real Estate and Urban Economics Association, 9, pp. 93-114.

Stanbury, W. and VerTinsky, I. (1985) Rent regulation: design characteristics and effects. Research Study No. 18, Ontario Commission of Inquiry into Residential Tenancies.

STEELE, M. and MIRON, J.R. (1984) Rent regulation, housing affordability problems, and market imperfections. Research Study No. 9, Ontario Commission of Inquiry into Residential Tenancies.

Stiglitz, J.E. and WeIss, A. (1981) Credit rationing in markets with imperfect information, American Economic Review, 71, pp. 393-410.

VORST, A.C.F. (1987) Optimal housing maintenance under uncertainty, Journal of Urban Economics, 21, pp. 209-227.

Williamson, O.E. (1985) The Economic Institutions of Capitalism. New York: Free Press. 